\title{
RESPONS PENYU TERHADAP CAHAYA UNTUK MITIGASI BYCATCH DALAM SKALA LABORATORIUM
}

\section{RESPONSE OF TURTLE AGAINST LIGHT FOR BYCATCH MITIGATION IN LABORATORY SCALE}

\author{
Ronny Irawan Wahju ${ }^{1}$, Mochammad Riyanto $^{1}$, Roza Yusfiandayani $^{1}$, Ganang Dwi Prasetyo ${ }^{2}$ \\ ${ }^{1}$ Departemen Pemanfaatan Sumberdaya Perikanan, \\ Fakultas Perikanan dan Ilmu Kelautan, Institut Pertanian Bogor \\ ${ }^{2}$ Politeknik Kelautan dan Perikanan Kupang, \\ Badan Riset dan SDM Kelautan dan Perikanan, Kementerian Kelautan dan Perikanan \\ Korespondensi: rwahyu06@gmail.com
}

\begin{abstract}
Research on the turtle's response to green Light Emitting Diode (LED) light emitting diode to reduce turtle bycatch was carried out on a laboratory scale. The aim of the study is to analyze the behavior response of turtles to green LED lights on a laboratory scale. The research used experimental laboratory by observing turtle behavior towards green light in controlled conditions. Testing was done by observing the response in the form of movements and speed of the juvenile turtle to the green LED lights. The turtle species that became the object of this observation were 11 green turtles (Chelonia mydas) with Curve Carapace Length (CCL) $45-50 \mathrm{~cm}$ carapace length. The results showed that sea turtles had visual sensitivity conditions and levels, and showed the same response to each treatment. The use of green LED lights provides an avoidance response to turtles. Based on the avoidance response, green LED lights can be used as an alternative in reducing turtle bycatch in gillnet fishing activities.
\end{abstract}

Keyword: bycatch, green turtle, LED Light, response

\begin{abstract}
ABSTRAK
Penelitian tentang respons penyu terhadap lampu Light Emitting Diode (LED) warna hijau untuk mengurangi bycatch penyu telah dilakukan dalam skala laboratorium. Tujuan dari penelitian adalah untuk menganalisis respons tingkah laku penyu terhadap lampu LED hijau pada skala laboratorium. Metode penelitian yang digunakan adalah eksperimental laboratorium dengan melakukan observasi tingkah laku penyu terhadap cahaya hijau dalam kondisi yang terkontrol. Pengujian dilakukan dengan mengamati respons berupa pergerakan dan kecepatan tukik terhadap lampu LED hijau. Spesies penyu yang menjadi objek pada pengamatan ini adalah tukik penyu hijau (Chelonia mydas) sebanyak 11 ekor dengan ukuran panjang karapas CCL 45-50 cm. Hasil penelitian menunjukkan bahwa penyu memiliki kondisi dan tingkat sensitivitas visual dan menunjukkan respons yang sama terhadap setiap perlakuan. Penggunaan Lampu LED hijau memberikan respons penghindaran terhadap penyu. Berdasarkan respons penghindaran tersebut, lampu LED hijau dapat digunakan sebagai alternatif dalam mereduksi bycatch penyu pada kegiatan perikanan gillnet.
\end{abstract}

Kata kunci: bycatch, lampu LED, penyu hijau, response 


\section{PENDAHULUAN}

Bycatch adalah hasil tangkapan sampingan atau non-target catch dari aktivitas penangkapan ikan (Hall 1996; Davies et al. 2009) yang saat ini bycatch merupakan isu utama pada perikanan global (Hall et al. 2000; Casale 2011) dan menjadi ancaman serius terhadap penurunan populasi megafauna laut di dunia seperti penyu (Lewison et al. 2004; Wallace et al. 2010), dimana penyu termasuk hewan endangered species (IUCN 2016). Penyu merupakan reptil yang hidup di laut, memiliki siklus hidup yang panjang dan kemampuan reproduksi yang rendah (Frazer 1992), serta mampu bermigrasi dalam jarak yang jauh (Wallace et al. 2010; Hamann et al. 2010).

Alat tangkap yang menangkap penyu sebagai bycatch diantaranya gillnet multifilament diperairan Paloh di Kalimantan Barat (Wahju et al. 2014, Prasetyo et al. 2017) pada long line sebesar 69\% dari jenis 69\% loggerheads (Read 2007) serta penyu lekang $<5 \%$ (Setyadji dan Nugraha 2012). Menurut Wahju et al. (2014) dan Suprapti (2012) jenis penyu yang tertangkap sebagai bycatch adalah jenis penyu hijau (Chelonia mydas) dan penyu sisik (Eretmochelys imbricate). Beberapa penelitian telah dilakukan dalam mitigasi penyu sebagai bycatch berdasarkan pada pengetahuan tentang kemampuan penglihatan dan tingkah laku penyu pada aktivitas penangkapan ikan (Schuyler et al. 2014).

Beberapa penelitian dalam upaya mengurangi bycatch penyu pada alat tangkap gillnet dengan memanfaatkan kemampuan penglihatan penyu telah banyak dilakukan, seperti penggunaan lampu tanda (marker light) cahaya putih (broader spectrum white) (Gilman et al. 2010), penggunaan lightstick dan lampu (Ortiz et al. 2016). Lampu LED yang digunakan pada penelitian ini merupakan jenis Electrolume Green-Single Colour (LP), yang merupakan modifikasi lampu dengan bentuk minimalis, dan dilengkapi 2 LED berwarna hijau, serta dioperasikan menggunakan baterai Alkaline AA. Uji coba penggunaan lampu LED hijau ini telah dilakukan di beberapa negara seperti, Meksiko, Peru, dan Chili yang menunjukkan bahwa dapat menurunkan tangkapan bycatch penyu sebesar 40-64\% tanpa menurunkan tangkapan target catch, serta nilai jual (catch value) hasil tangkapan cenderung meningkat (Wang et al. 2010; Ortiz et al. 2016). Penelitian yang telah dilakukan tersebut merupakan uji coba langsung penerapan di lapangan. Penelitian tentang bagaimana respons penyu terhadap lampu LED belum dilakukan, untuk menentukan bagaimana pola pergerakan, besaran intensitas cahaya minimal dan respons menghindar penyu belum dilakukan. Oleh sebab itu, diperlukan penelitian respons penyu pada skala laboratorium. Tujuan penelitian ini menganalisis respons tingkah laku penyu terhadap lampu LED hijau pada skala laboratorium.

\section{METODE PENELITIAN}

\section{Pengamatan tingkah laku penyu skala laboratorium}

Pengamatan tingkah laku penyu dilaksanakan di Laboratorium Stasiun Lapang Kelautan (SLK) Institut Pertanian Bogor. Alat yang digunakan selama penelitian skala laboratorium ini disajikan pada Tabel 1 .

Metode penelitian yang digunakan adalah eksperimental yang merupakan penelitian observasi di bawah kondisi buatan (artificial condition) yang terkontrol (Nazir 2009). Pengujian dilakukan dengan mengamati respons tukik terhadap lampu LED hijau. Spesies penyu yang menjadi objek pada pengamatan ini adalah tukik penyu hijau (Chelonia mydas) yang didatangkan dari Taman Pesisir Pantai Penyu Pangumbahan (Pangumbahan Turtle Park), Sukabumi, Jawa Barat $\left(07^{\circ} 19^{\prime} 08^{\prime \prime}\right.$ - 07'20'52" LS dan $106^{\circ} 19^{\prime} 37^{\prime \prime}$ - $106^{\circ} 20^{\prime} 07^{\prime \prime}$ BT) sebanyak 11 ekor dengan ukuran CCL 45-50 cm berumur 1-27 hari. Penelitian ini menggunakan tukik hasil penangkaran sebagai sampel penelitian untuk mengkaji respons penyu terhadap cahaya. Hal ini didasarkan, karena pada observasi lapang, penyu yang tertangkap didominasi oleh juvenile penyu hijau dengan ukuran $(\mathrm{CCL})<60,7 \mathrm{~cm}$. Penggunaan sampel penyu pada laboratorium berbeda dengan ukuran dan usia penyu yang tertangkap pada uji lapangan dianggap relevan untuk mereprentatifkan penyu diberbagai usia (Young et al. 2012). Tahapan yang dilakukan pada penelitian skala laboratoriun ini meliputi:

1. Tahap persiapan dan pemeliharaan tukik Penelitian ini dimulai dari persiapan bak pemeliharaan. Bak untuk pemeliharaan tukik merupakan bak fiber dengan diameter $150 \mathrm{~cm}$ dan tinggi $50 \mathrm{~cm}$, dengan dilengkapi saluran pembuangan air. Bak yang telah disiapkan, diisi dengan air laut sebanyak 
120 liter yang menghasilkan kedalaman 5,5 $\mathrm{cm}$. Kondisi air laut antara lain, salinitas $28-30 \%$ dan suhu perairan $25-27{ }^{\circ} \mathrm{C}$. Tukik diberi makan secara rutin sebanyak 2 kali sehari, yaitu pagi (07.00 - 08.00) dan malam (19.00 - 20.00). Jenis pakan yang digunakan adalah udang rucah (udang putih). Pergantian air dilakukan setiap hari sebanyak 1 kali dalam sehari.

\section{Tahap penelitian}

Uji coba berlangsung ketika tukik berumur 14-46 hari dengan ukuran CCL 52,5-93 mm. Tukik yang dilakukan pengamatan dengan ukuran dan umur masing-masing tukik, disajikan pada Tabel 2.

Bak Eksperimen dirancang sedemikian rupa untuk proses pengamatan tingkah laku penyu. Bak eksperimen merupakan bak fiber dengan diameter $150 \mathrm{~cm}$ dengan tinggi $50 \mathrm{~cm}$, dilengkapi dengan saluran pembuangan air. Dasar bak eksperimen diberi garis bantu setiap interval $10^{\circ}$ yang terdiri dari $0^{\circ}-360^{\circ}$ untuk memudahkan pengamatan dalam tahap analisis video. Bak eksperimen dilengkapi dengan 2 shelter dengan ukuran panjang 30 $\mathrm{cm}$ dan diameter 5 inci berbahan polyvinile chloride (PVC). Shelter ini terbuat dari paralon berdiameter 5 inci dengan panjang $30 \mathrm{~cm}$, tujuannya adalah sebagai manipulasi tempat yang memiliki minimalisir cahaya selama pengujian dengan penggunaan lampu LED. Proses perekaman video untuk selanjutnya dianalisis, digunakan Close Circuit Television (CCTV) nightvision yang memiliki kemampuan 720p dan 4 fps dengan menghasilkan wide mode. Sistem operasi CCTV tersebut merupakan Internet Protocol (IP) kamera, merupakan kamera digital untuk pemantauan yang dapat mentransfer data melalui jaringan komputer dan internet. Jaringan internet sangat dibutuhkan untuk mengoperasikan kamera tersebut, sehingga digunakan modem beserta router untuk memancarkan internet, karena di laboratorium tidak tersedia jaringan internet. Jarak pemasangan kamera untuk mendapatkan keseluruhan bak pengamatan adalah $245 \mathrm{~cm}$. Ilustrasi bak eskperimen dapat dilihat pada Gambar 1.

Tabel 1. Daftar alat yang digunakan pada penelitian laboratorium

\begin{tabular}{|c|c|c|c|}
\hline No. & Alat & Tipe/Spesifikasi & Parameter yang diukur \\
\hline 1 & Lampu LED hijau & LP-Eletrolume green & Objek penelitian \\
\hline 2 & 2 bak pengamatan & Bahan fiber, diameter $150 \mathrm{~cm}$ & $\begin{array}{l}\text { Tempat pemeliharaan dan } \\
\text { eksperimen }\end{array}$ \\
\hline 3 & 2 Shelter & Paralon PVC 5 inci & Objek penelitian \\
\hline 4 & Kamera infrared & $\begin{array}{l}\text { Close Circuit Television (CCTV) } \\
\text { Xiaomi Yi-Night Vison ( } 4 \mathrm{fps})\end{array}$ & Perekam selama penelitian \\
\hline 5 & Infrared tambahan & $\begin{array}{l}\text { Close Circuit Television (CCTV) } \\
\text { Portable Daniu DB-BO1 }\end{array}$ & Penambah infrared \\
\hline 6 & Laptop & ASUS X450 C & Pengendali router \\
\hline 7 & Router & Vodafone WIFi Sharing Dock & $\begin{array}{l}\text { Pemancar koneksi WIFi ke } \\
\text { kamera CCTV Xiaomi }\end{array}$ \\
\hline 8 & Modem & Huawei Mobile Broadband E3131 & Sumber jaringan internet \\
\hline
\end{tabular}

Tabel 2. Nilai skor indeks respon berdasarkan pergerakan tukik

\begin{tabular}{ccll}
\hline No. & Skor indeks & \multicolumn{1}{c}{ Respons } & \multicolumn{1}{c}{ Kriteria } \\
\hline 1 & $0-1$ & Tidak aktif & $\begin{array}{l}\text { Hampir tidak terdapat gerakan, flipper depan mau- } \\
\text { pun belakang tidak bergerak. } \\
\text { Bergerak pasif, pergerakan hanya ditunjukkan dari } \\
\text { salah satu flipper depan atau belakang. } \\
2\end{array}$ \\
$1,1-2$ & Pasif & Aktif & $\begin{array}{l}\text { Berenang namun tidak sangat aktif seperti skor 4, } \\
\text { pergerakan flipper depan dan belakang tidak cepat. }\end{array}$ \\
3 & $2,1-3$ & Sangat aktif & $\begin{array}{l}\text { Berenang sangat aktif, pergerakan flipper depan dan } \\
\text { belakang bergerak sangat aktif, pergerakan cepat. }\end{array}$ \\
\hline
\end{tabular}




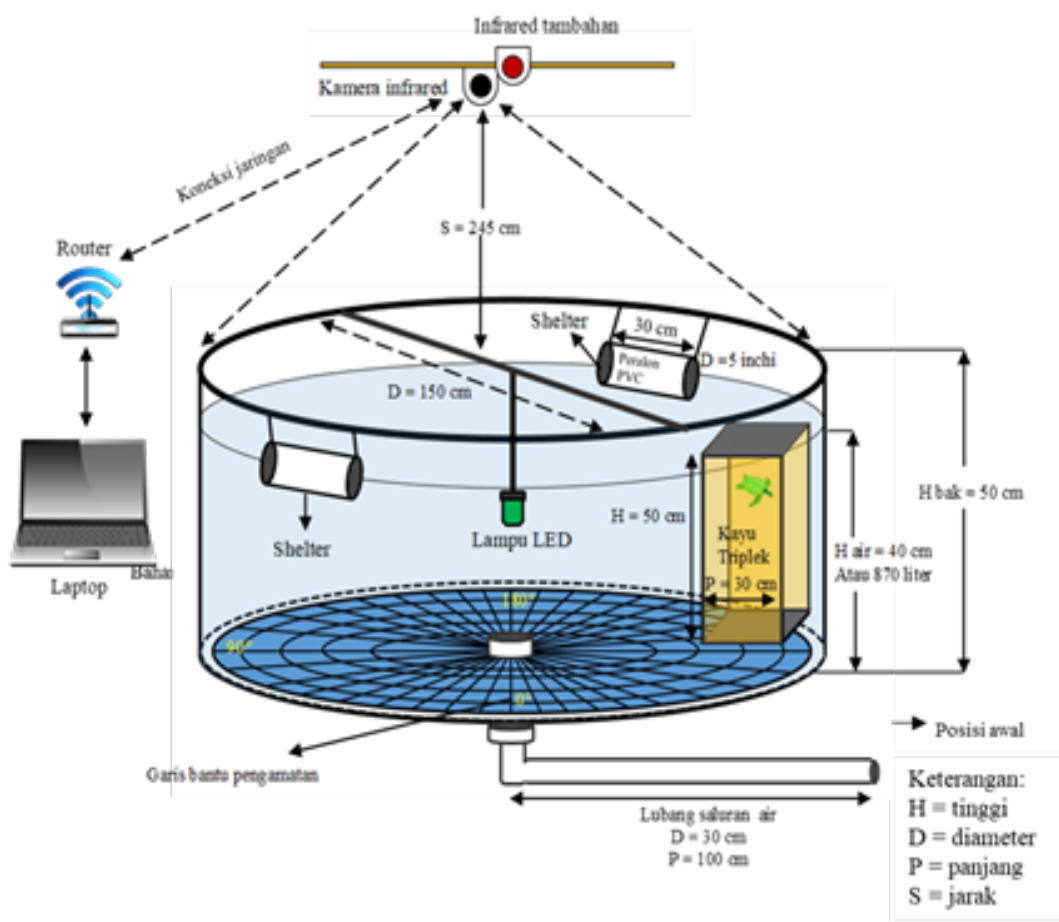

Gambar 1. Ilustrasi bak eksperimen

Tukik diuji satu per satu, dengan pengujian kontrol (tanpa lampu LED) dan eksperimen (dengan lampu LED). Pengamatan setiap tukik dilakukan pengulangan 2 kali, pengulangan dilakukan di hari berikutnya (tidak langsung dilakukan pengulangan). Pengamatan dilakukan selama 20 menit untuk 1 tukik, dengan 10 menit pengamatan kontrol dan 10 menit kemudian pengamatan eskperimen sesuai dengan protokol penelitian yang dilakukan oleh Wang et al. (2007). Langkah pertama pada pengamatan kontrol, tukik diletakkan di posisi awal dan dibiarkan selama 3 menit, selanjutnya ruang posisi awal dibuka, dan tukik dibiarkan selama 10 menit untuk dilakukan pengamatan. Tukik yang telah selesai pada pengamatan kontrol, kemudian dimasukkan kembali ke dalam ruang posisi awal, dan dibiarkan 3 menit, untuk dilanjutkan pada pengamatan eksperimen. Lampu LED dihidupkan, kemudian ruang posisi awal dibuka, dan tukik dibiarkan selama 10 menit untuk dilakukan pengamatan. Tahap ini kemudian dilanjutkan kembali dengan tukik selanjutnya.

\section{Tahap analisis video}

Hasil rekaman video kemudian dianalisis menggunakan metode tracking manual video analysis dengan software QuickTime player 7.6. Pergerakan tukik setiap detiknya dianalisis dan diberi skoring.
Nilai skoring tersebut, disajikan pada Tabel 2. Lebih lanjut, Ilustrasi penilaian terhadap respons tukik selanjutnya disajikan pada Gambar 4. Output yang diharapkan adalah hasil respons pada setiap menitnya (yang dianalisis setiap detik) selama 10 menit pengamatan. Respons pergerakan yang ditunjukkan oleh tukik menggambarkan responnya terhadap setiap perlakuan (kontrol dan eksperimen).

Shelter sebagai tempat berlindung bagi tukik selama pengujian. Hal ini untuk mengetahui apakah tukik yang berespons khususnya pada perlakuan eksperimen hendak masuk ke dalam shelterini, sehingga intensitas masuknya tukik ke dalam shelter diperhitungkan sebagai pengamatan. Pergerakan tukik ditracking dan dihitung berdasarkan fps (frame per second), untuk melihat pola pergerakan selama pengamatan berlangsung. Kamera perekam selama penelitian, memiliki spesifikasi $4 \mathrm{fps}$ atau dalam setiap 1 detik terdapat 4 frame (gambar). Perpindahan tukik dari lokasi $1 \mathrm{ke}$ lokasi lainnya ditracking setiap frame-nya, dan dihitung berapa jumlah frame pada setiap perpindahannya. Dengan demikian, maka dapat diketahui pola dan kecepatan tukik yang berpindah dari pergerakannya namun berdasarkan frame pada video yang dihasilkan oleh kamera yang digunakan.

Respons tukik dianalisis berdasarkan skoring setiap waktu pengamatan. Nilai skoring respons setiap detik selama waktu 
pengamatan (setiap menit selama 10 menit) kemudian di rata-rata, dengan persamaan sebagai berikut.

$$
\overline{A_{i}}=\frac{\sum A_{i}}{n_{i}}
$$

Keterangan:

$\bar{A}_{i} \quad=$ rata-rata repsons pada menit $\mathrm{ke}-i$

$\sum A_{i}=$ jumlah skor respons pada menit ke- $i$

$n_{i} \quad=$ jumlah data pada menit $\mathrm{ke}-i$

Uji statistik dilakukan, untuk mengetahui respons masing-masing tukik terhadap setiap perlakuan yaitu perlakuan kontrol dan eksperimen, selanjutnya untuk mengetahui pengaruh penggunaan lampu LED terhadap laju respons tukik setiap watu pengamatan. Sebelum dilakukan analisis statistik, data tersebut diuji kenormalannya menggunakan Kolmogorov-smirnov test di software SPSS 16.00. Uji statistik untuk mengetahui respons masing-masing tukik terhadap kedua perlakuan setiap waktu pengamatan, menggunakan analisa ragam klasifikasi satu arah (ANOVA single factor) pada software SPSS 16.00 dengan nilai a
$95 \%(0,05)$

\section{Profil lampu LED hijau}

Penggunaan lampu LED digunakan berwarna hijau dengan tipe Electrolume green-single colour (LP) yang dioperasikan dengan baterai Alkaline AA 1,5 volt sebanyak 2 buah. Spesifikasinya, antara lain menghasilkan warna cahaya hijau, diameter chasing berukuran 4,5 cm, tinggi chasing berukuran $11 \mathrm{~cm}$, bahan chasing adalah acrylic sehingga mampu digunakan pada kedalaman hingga $30 \mathrm{~m}$, panjang gantungan lampu berukuran $15 \mathrm{~cm}$, tegangan listrik sebesar 3,7 volt, ketahanan penggunaan 2 buah baterai pada 1 lampu LED selama 168 hingga 500 jam. Lampu ini merupakan produksi dari program Smartgearyang telah diinternalisasikan oleh WWF (World Wild Fund)-US dan National Oceanic and Atmospheric Administration (NOAA). Pengukuran intensitas dan radiasi cahaya lampu LED hijau di udara menggunakan alat lightmeter (ILT 5000 research radiometer), nilai intensitas cahaya tertinggi sebesar $0,00124 \mathrm{watt} / \mathrm{cm}^{2}$ pada sudut $140^{\circ}$ (Gambar 2).

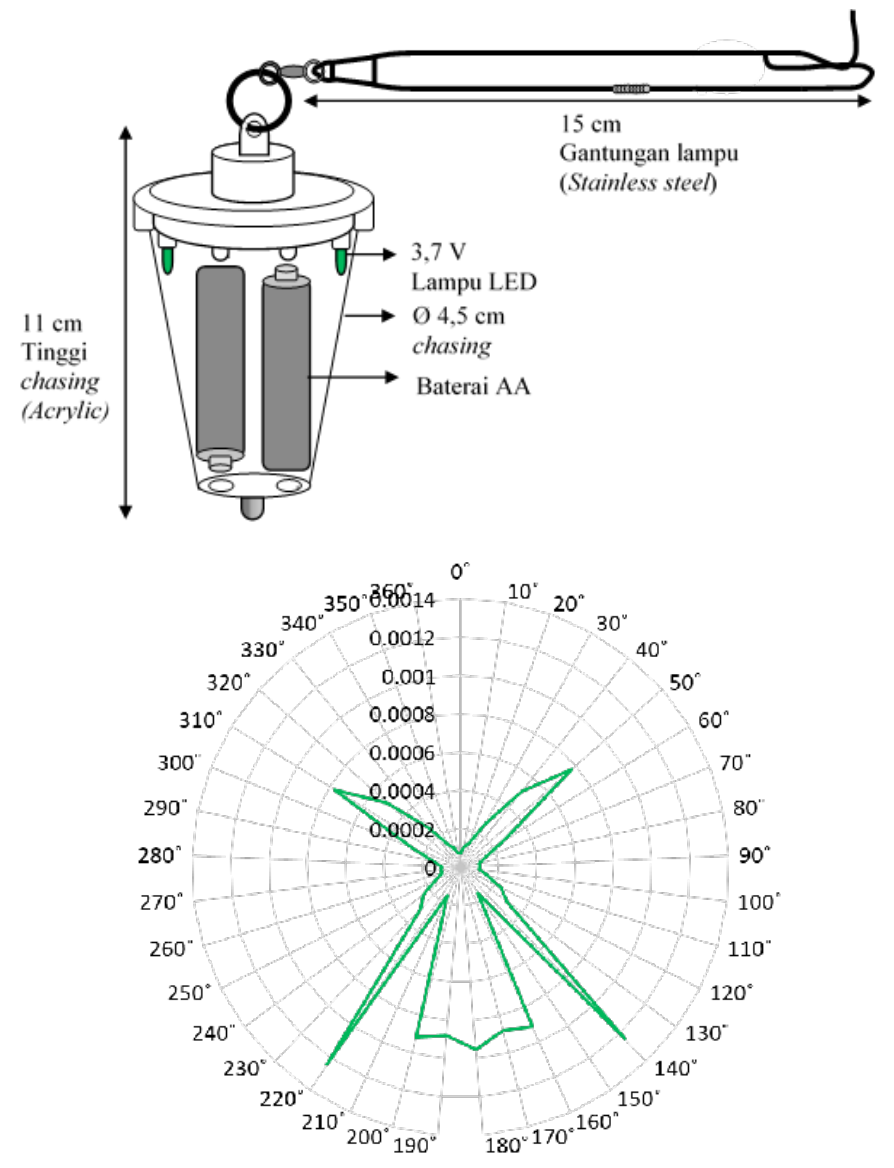

Gambar 2. Gambar lampu dan profil intensitas cahaya lampu LED hijau yang digunakan pada pengukuran $1 \mathrm{~m}$ dengan sudut $360^{\circ}$ 
Nilai puncak spektral yang diukur $5 \mathrm{~cm}$ dari sumber LED electrolume hijau ini, didapatkan nilai sebesar $530 \mathrm{~nm}$ pada $6,4 \mu \mathrm{W}$ (Gless et al. 2008). Lebih lanjut, pengukuran terhadap LP-green electrolume didapatkan nilai spektral $524,59 \mathrm{~nm}$, dengan nilai absolute irradiance $\left(\mathrm{mW} / \mathrm{cm}^{2} / \mathrm{nm}\right)$ pada sudut $180^{\circ}$ sebesar 0,666 , pada sudut $135^{\circ}$ sebesar 0,206, sudut $90^{\circ}$ sebesar 0,0576, dan sudut $0^{\circ}$ sebesar 0,00845 (Wang dan Swimmer 2014).

\section{HASIL DAN PEMBAHASAN}

\section{Hasil penelitian}

Tukik yang dilakukan uji coba berjumlah 11 ekor dengan masing-masing dilakukan pengulangan 2 kali. Laju respons masing-masing tukik terhadap perlakuan kontrol dan eksperimen selama 10 menit, dapat dilihat pada Gambar 3. Tampak bahwa, setiap tukik memberikan respons yang tidak berbeda nyata $(p>0,05)$ baik terhadap perlakuan kontrol dan eksperimen selama pengamatan.

Pengamatan menit pertama pada perlakuan kontrol didapatkan nilai respons (rerata $\pm \mathrm{SD}$ ) sebesar 1,64 $\pm 0,19$, sedangkan pada perlakuan eksperimen sebesar 3,75 \pm 0,10 . Pada jarak perpindahan yang sama, respons tukik pada perlakuan eksperimen menunjukkan pergerakan yang lebih cepat dibandingkan dengan kontrol. Hubungan antara jumlah frame dengan waktu (detik) berbanding lurus, yang berarti semakin banyak jumlah frame selama pergerakan maka lama waktunya akan semakin tinggi. Rata-rata lama pergerakan tukik (rerata \pm $\mathrm{SD}$ ) pada perlakuan kontrol yaitu berjumlah
$164 \pm 15,14$ frame yang berkisar 131-195 frame, dengan waktu sebesar $41 \pm 3,79$ detik yang berkisar 33-49 detik. Rata-rata lama pergerakan tukik (rerata $\pm \mathrm{SD}$ ) pada perlakuan eksperimen berjumlah $14 \pm 4,24$ frame yang berkisar 8-21 frame, dengan waktu selama $4 \pm 1,06$ detik yang berkisar 2-5 detik. Analisis statistik menunjukkan bahwa terdapat pengaruh penggunaan lampu LED pada perlakuan eksperimen terhadap pola respons pergerakan tukik baik berdasarkan jumlah frame maupun lama waktunya (detik).

Secara deskriptif, pola respons sangat aktif tukik pada perlakuan eksperimen ditunjukkan selain dari gerakannya juga tampak bahwa lintasan perpindahan yang jauh saat bergerak, ditempuh dengan waktu yang singkat. Berbanding terbalik dengan perlakuan kontrol, respons pasif ditunjukkan ketika pergerakan berpindah pada lintasan dengan jarak yang relatif dekat namun ditempuh dengan waktu yang lama. Perpindahan tukik pada perlakuan kontrol juga hanya ke beberapa titik atau dengan kata lain pergerakannya tidak sejauh seperti pada pergerakan di perlakuan eksperimen. Pola respons tukik pada perlakuan eksperimen secara keseluruhan, tampak bahwa tukik mengalami disorientasi arah (bergerak ke segala arah), dengan beberapa kali mendekati lampu, namun tidak sempat menabrak lampu. Pola respons tukik pada perlakuan kontrol secara keseluruhan, tampak bahwa cenderung bergerak pasif, dan hanya bergerak pada lokasi tertentu saja atau tidak ke semua arah. Pola respons yang sering terbentuk selama perlakuan eksperimen terdiri atas 4 pola, disajikan pada Gambar 4.

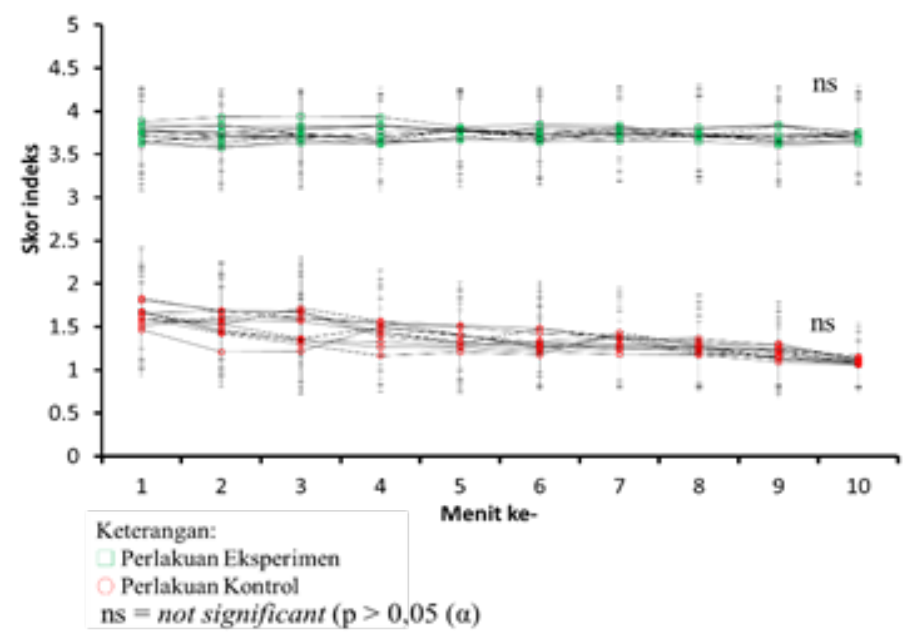

Gambar 3. Laju respons masing-masing tukik terhadap perlakuan kontrol dan eksperimen selama waktu pengamatan 
(A)

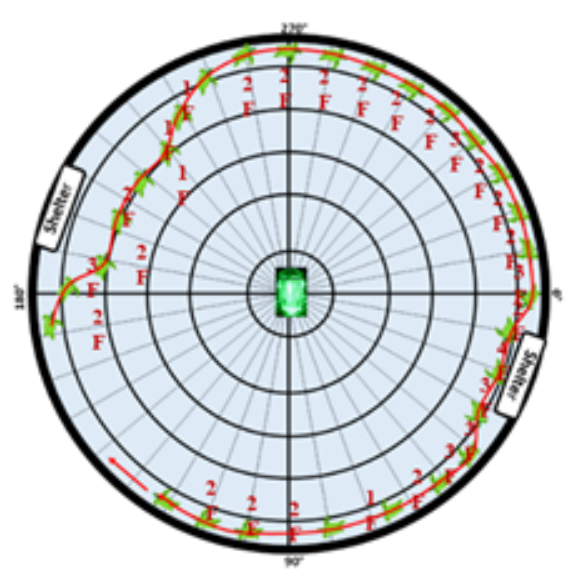

- Jumlah perpindahan : 28

- Jumlah frame : $: 60$

- Waktu

(C)

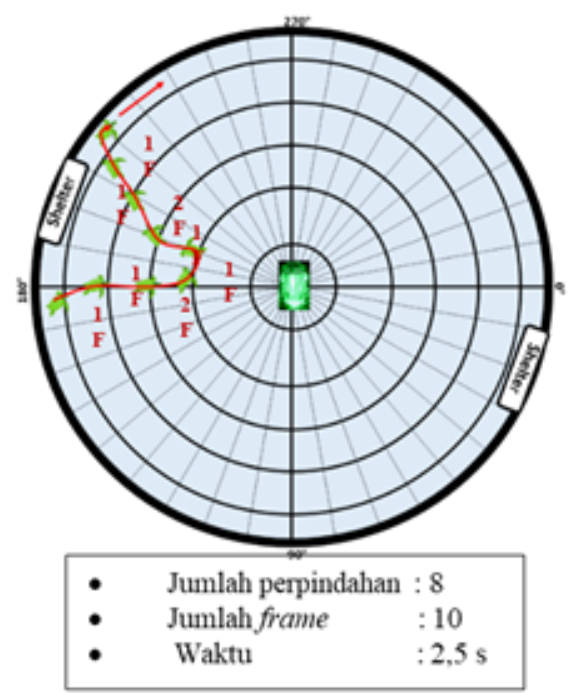

(B)

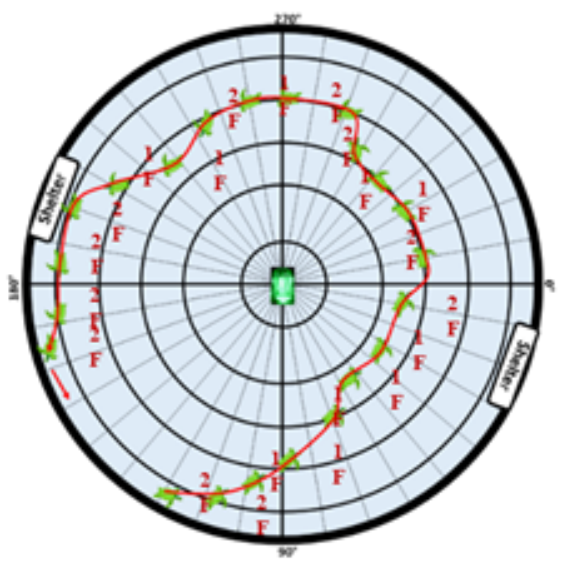

- Jumlah perpindahan : 21

- Jumlah frame $\quad: 32$

- Waktu :8s

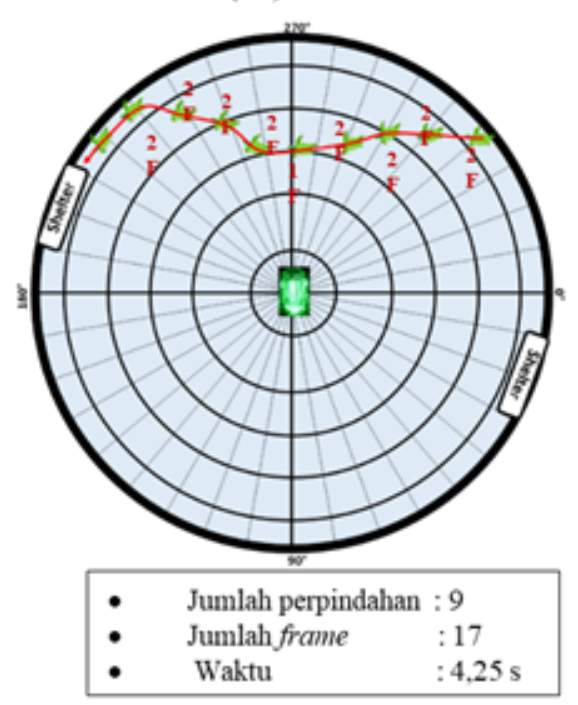

Gambar 4. Pola respons tukik selama perlakuan eksperimen; Keterangan: gambar tampak atas; (A) Pola 1; (B) Pola 2; (C) Pola 3; (D) Pola 4

\section{Pola 1}

Tukik bergerak dengan mengelilingi garis terluar/pinggir bak eksperimen. Selama bergerak mengelilingi pinggir bak eskperimen, terkadang tukik keluar dari pinggir bak eksperimen, meskipun demikian tidak menghampiri lampu, namun kembali bergerak menuju garis terluar/pinggir bak eksperimen. Pola 1 merupakan pola yang sering terbentuk selama perlakuan eksperimen, dimana bersamaan respons sangat aktif pada tukik dengan jumlah perpindahan 28 kali ditempuh selama 60 frame atau 15 detik.

\section{Pola 2}

Tukik bergerak mengelilingi lampu, namun tidak sampai menabrak lampu tersebut, dimana tampak jarak terdekat dengan lampu hingga garis kedua (20 $\mathrm{cm})$. Pergerakan tukik mengelilingi lampu ini bersamaan respons sangat aktif pada tukik, dengan jumlah perpindahan $21 \mathrm{kali}$ ditempuh selama 32 frame atau 8 detik.

\section{Pola 3}

Tukik mula-mula bergerak dipinggir bak eskperimen, kemudian bergerak menuju lampu hingga berjarak di garis kedua (20 cm), namun berbelok kembali menuju pinggir bak eksperimen, bersamaan dengan respons sangat aktif. Pergerakan perpindahan sebanyak 8 kali ditempuh selama 10 frame atau 2,5 detik. 


\section{Pola 4}

Tukik yang mula-mula bergerak di sisi bak eskperimen, bergerak menuju lampu hingga berjarak di garis $3(30 \mathrm{~cm})$, kemudian berbelok kembali dan bergerak lurus menuju sisi bak eksperimen, selanjutnya menuju ke shelter dan masuk ke dalam shelter. Pergerakan pada pola ini bersamaan dengan respons sangat aktif pada tukik, dengan perpindahan sebanyak 9 kali ditempuh selama 17 frame atau 4,25 detik.

Respons tukik pada perlakuan kontrol secara keseluruhan tampak pasif dengan menunjukkan sedikit gerakan, pola respon yang sering terbentuk terdiri atas 3 pola, disajikan pada Gambar 5 .

\section{Pola 1}

Tukik bergerak dari posisi awal dengan respons pasif menuju ke titik pusat yang merupakan lokasi pemasangan lampu.
Tukik berpindah sebanyak 6 kali ditempuh selama 198 frame atau 49,5 detik hingga titik pusat. Setelah di titik pusat, tukik diam selama beberapa waktu.

\section{Pola 2}

Tukik bergerak dari posisi awal dengan repon pasif. Jumlah perpindahan tukik sebanyak 3 kali, yaitu pada garis ke $5(50 \mathrm{~cm})$, garis ke $4(40 \mathrm{~cm})$, dan garis ke $3(30 \mathrm{~cm})$. Perpindahan tukik selama 158 frame atau 39,5 detik, kemudian tukik diam selama beberapa waktu.

\section{Pola 3}

Tukik bergerak dari posisi awal dengan respons pasif, dengan berpindah sebanyak 4 kali, dimana secara keseluruhan di garis $5(50 \mathrm{~cm})$ dan garis ke $4(40 \mathrm{~cm})$. Lama perpindahan tukik berjumlah 166 frame atau 41,5 detik. Selanjutnya, tukik diam selama beberapa waktu di posisi tertakhirnya.
(A)

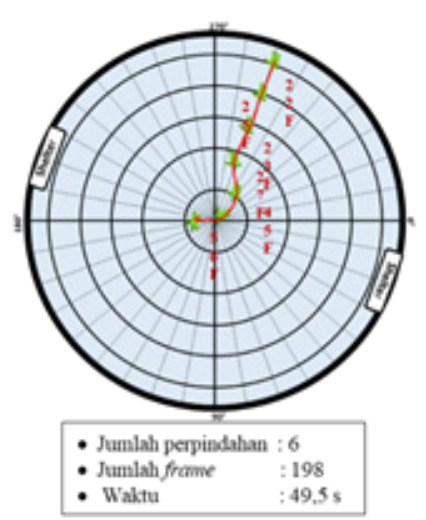

(B)

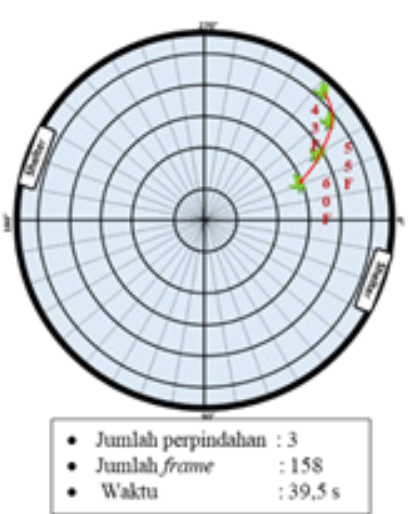

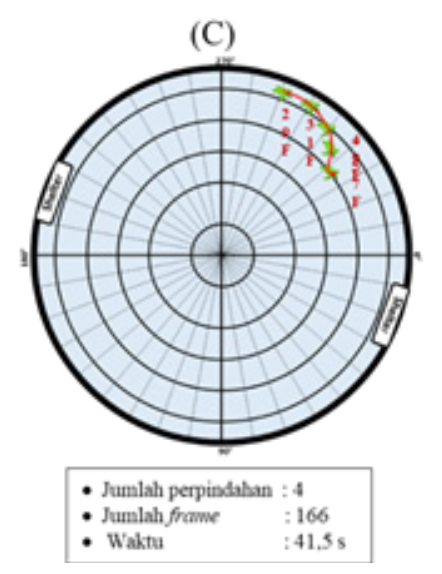

Gambar 5. Pola respons tukik selama perlakuan kontrol; Keterangan: gambar tampak atas; (A) Pola 1; (B) Pola 2; (C) Pola 3 


\section{Pembahasan}

Respons penghindaran penyu juga ditunjukkan pada analisis tingkah laku penyu skala laboratorium yang telah dilakukan pada penelitian ini dengan menggunakan sampel tukik penyu hijau. Masing-masing tukik menunjukkan respons yang sama terhadap kedua perlakuan (kontrol dan eksperimen) selama pengamatan berlangsung. Hal ini dapat diintepretasikan, bahwa masing-masing penyu dalam kondisi dan tingkat sensitivitas visual yang sama, sehingga apabila pada perlakuan eksperimen memiliki respons sangat aktif maka semua penyu berespons sama, sebaliknya apabila pada perlakuan kontrol semua penyu berespons pasif. Hasil yang relatif sama juga ditunjukkan pada beberapa penelitian sebelumnya (Witherington dan Bjorndal 1991). Penghindaran tukik terhadap lampu LED (perlakuan eksperimen) dapat diidentifikasi berdasarkan peningkatan respons tukikyang menjadi sangat aktif, tingginya intensitas masuk ke dalam shelter, dan cepatnya pergerakan perpindahan pada jarak yang ditempuh berdasarkan frame per second, dibandingkan ketika tanpa menggunakan lampu LED. Penggunaan lampu LED berpengaruh terhadap meningkatnya keaktifan tukik dalam bergerak, dimana tampak tukik mengalami disorientasi yang merupakan bergerak ke segala arah untuk mencoba menghindari lampu LED yang dipasang. Hal ini serupa dengan penelitian Witherington dan Bjorndal (1991), dimana tukik penyu hijau memberikan respons lebih aktif dengan bergerak ke segala arah ketika perlakuan menggunakan cahaya yang memiliki panjang gelombang $520 \mathrm{~nm}$.

Peningkatan respons tukik pada perlakuan eksperimen menyebabkan perpindahan pada jarak yang jauh dapat ditempuh dengan waktu yang relatif singkat, berbanding terbalik pada perlakuan kontrol dimana perpindahan tukik cenderung sedikit namun membutuhkan waktu berpindah yang sangat lama. Respons tukik yang sangat aktif cenderung berenang ke arah horizontal, dimana hal ini merupakan hal yang normal dilakukan tukik penyu hijau ketika melarikan diri dari suatu gangguan (Davenport et al. 1984). Peningkatan respons aktif tukik ketika berenang pada perlakuan eksperimen diduga terjadi vigorous swimming (berenang secara cepat). Vigorous swimming terjadi ketika tukik hendak menghindari sesuatu yang mengganggu, dengan menghasilkan kecepatan 10 hingga $50 \mathrm{~cm} / \mathrm{s}$. Hal ini juga terlihat dari peningkatan pergerakan flipper secara cepat hingga hampir membentuk sudut $90^{\circ}$ (Davenport etal. 1984). Berbanding terbalik pada perlakuan kontrol, minimnya pergerakan flipper menghasilkan respons pasif sehingga perpindahan pada jarak yang dekat ditempuh dengan waktu yang sangat lama.

Tukik yang berupaya menghindari lampu, ditunjukkan dengan berlindung pada shelter yang disediakan. Shelter untuk memanipulasi wilayah yang minim cahaya, sehingga tukik yang berespons aktif akibat adanya cahaya berusaha masuk ke dalam shelter agar tidak terpengaruh oleh cahaya yang dihasilkan oleh lampu LED. Menurut Wyneken et al. (2013), pada dasarnya tukik yang berenang bebas menuju perairan akan mencari tempat perlindungan dari berbagai faktor yang mengancam atau mengganggu. Hasil penelitian ini sama dengan penelitian sebelumnya dimana penggunaan lampu LED hijau menyebabkan respons penghindaran oleh tukik penyu belimbing (Dermochelys coriacea) (Gless et al. 2008). Penyu memiliki kemampuan visual yang baik terhadap berbagai gelombang cahaya, sehingga hal ini dapat dijadikan strategi dalam mereduksi tangkapan penyu pada aktivitas perikanan (Lohmann et al. 2008; Bartol et al. 2002; Swimmer et al. 2005; Southwood et al. 2008; Schuyler et al. 2014; Gless et al. 2008; Gilman et al. 2010).

Penyu menghindari cahaya disebabkan kemampuan penglihatan penyu dalam menerima spektrum cahaya tertentu. Retina pada organ penglihatan penyu hijau berkembang sangat baik dimana sel kon fotoreseptor pada organ penglihatan penyu hijau mengandung oil droplets, tidak seperti ikan pada umumnya (Southwood et al. 2008). Oil droplets yang terkandung di dalam fotoreseptor berfungsi sebagai filter yang dapat berperan dalam pergerakan sensitivitas sel cone terhadap panjang gelombang pendek maupun yang terpanjang (Crognale et al. 2008; Mathger et al. 2007). Oil droplets pada penyu hijau mengandung beberapa warna dengan senstivitas puncak pada cahaya biru (440 nm), cahaya hijau (502 $\mathrm{nm}$ ), dan cahaya kuning (562 $\mathrm{nm})$. Warna pada oil droplets tersebut diduga disebabkan terdapatnya berbagai jenis carotenoid yang khas, dimana spektrum cahaya puncak tersebut dapat diserap dalam bentuk ekstrak pelarut organik (organic solvent extracts) dari retina (Liebman dan Granda 
1975). Oleh sebab itu, terdapatnya oil droplets pada sel cone reseptor, memperluas penglihatan pada gelombang cahaya pendek maupun tinggi pada penyu hijau (Levenson 2004; Ventura et al. 2001). Penglihatan penyu hijau (Chelonia mydas) responsif pada gelombang cahaya yang berkisar 400$700 \mathrm{~nm}$, dengan puncaknya pada gelombang cahaya dikisaran 500-580 $\mathrm{nm}$, namun pada gelombang cahaya di atas $650 \mathrm{~nm}$ dan di bawah $500 \mathrm{~nm}$, terjadi penurunan sensitivitas penglihatan (Eckert et al. 2006; Levenson et al. 2004; Witherington dan Bjorndal 1991; Granda dan O'Shea 1972). Panjang gelombang cahaya lampu LED hijau berada pada kisaran $530 \mathrm{~nm}$ (Gless et al. 2008; Wang dan Swimmer 2014), sehingga pemanfaatan cahaya berwarna hijau memberikan dampak terhadap penyu untuk menghindari cahaya dari lampu LED yang dipasang pada alat tangkap gillnet. Berdasarkan hasil penelitian bahwa penyu memiliki sensitivitas dan respons untuk menghindari lampu LED Hijau, maka lampu LED Hijau dapat digunakan dalam upaya mereduksi bycatch penyu pada perikanan gillnet.

\section{KESIMPULAN DAN SARAN}

\section{Kesimpulan}

Respons penyu terhadap lampu LED menunjukkan kondisi dan tingkat sensitivitas yang sama untuk setiap perlakuan. Penyu memberikan respons penghindaran terhadap lampu LED hijau perlakuan.

\section{Saran}

Perlu dilakukan penelitian lebih lanjut terkait tingkah laku penyu terhadap lampu LED hijau dengan intensitas yang berbeda untuk umur penyu yang berbeda.

\section{DAFTAR PUSTAKA}

Bartol SM, Musick JA, Ochs AL. 2002. Visual Acuity Tresholds of Juvenile Loggerhead Sea Turtles (Caretta caretta): An Electrophysiological Approach. Journal of Comparative Physiology. 187: 953-960.

Casale P. 2011. Sea Turtle Bycatch in The Mediterranean. Journal of Fish and Fisheries. 12: 299-316.
Crognale MA, Eckert SA, Levenson DH, Harms CA. 2008. Leatherback Sea Turtle (Dermochelys coriacea) Visual Capacities and Potential Reduction of Bycatch by Pelagic Longline Fisheries. Journal Endangered Species Research. 5: 249-256.

Davenport J, Munks SA, Oxford PJ. 1984. A Comparison of the Swimming of Marine and Freshwater Turtles. Proceedings of the Royal Society of London: Biological Sciences. 220: 447-475.

Davies RWD, Cripps SJ, Nickson A, Porter G. 2009. Defining and Estimating Global Marine Fisheries Bycatch. Journal Marine Policy. 33: 661-672.

Eckert S, Levenson DH, Crognale MA. 2006. The Sensory Biology of Sea Turtles: What Can They See, and How Can This Help Them Avoid Fishing Gear. Dalam Sea Turtle and Pelagic Fish Sensory Bioloy: Developing Techniques to Reduce Sea Turtle Bycatch in Longline Fisheries (Edited by: Swimmer Y, Brill, R). Honolulu, Hawaii (USA): Technical Memorandum NMFS-PIFSC-7, National Oceanic and Atmospheric Administration.

Frazer NB. 1992. Sea Turtle Conservation and Halfway Technology. Journal of Conservation Biology. 6: 179-184.

Gilman E, Gearhart J, Price B, Eckert S, Milliken $\mathrm{H}$, Wang $\mathrm{JH}$, Swimmer $\mathrm{Y}$, Shiode D, Abe O, Peckham SH, Chaloupka M, Hall M, Mangel $\mathrm{J}$, Alfaro-Shigueto J, Dalzell P, Ishizaki A. 2010. Mitigating Sea Turtle Bycatch in Coastal Passive Net Fisheries. Journal of Fish and Fisheries. 11: 57-88.

Gless JM, Salmon M, Wyneken J. 2008. Behavioral Responses of Juvenile Leatherbacks (Dermochelys coracea) to Lights Used in the Longline Fishery. Journal Endangered Species Research. 5: 239-247.

Granda AM, O'Shea PJ. 1972. Spectral Sensitivity of the Green Turtle (Chelonia mydas) Determined by Electrical Responses to Heterochromatic Light. Journal of Brain, Behaviour, and Evolution. 5: 143-154.

Hall MA. 1996. On Bycatches. Journal Fish Biology and Fisheries. 6: 319-352.

Hall MA, Alverson DL, Metuzals KI. 2000. Bycatch: Problem and Solutions. 
Marine Pollution Bulletin. 41: 204219.

Hamann M, Godfrey MH, Seminoff JA, Arthur K, Barata PCR, Bjorndal KA, Bolten AB, Broderick AC, Campbell LM, Carreras C, Casale P, Chaloupka M, Chan SKF, Coyne MS, Crowder LB, Diez CE, Dutton PH, Epperly SP, FitzSimmons NN, Formia A, Girondot M, Hays GC, Cheng IJ, Kaska Y, Lewison RL, Mortimer JA, Nichols WJ, Reina RD, Shanker K, Spotila JR, Tomas J, Wallace BP, Work TM, Zbinden J, Godley BJ. 2010. Global Research Priorities for Sea Turtles: Informing Management and Conservation in the 21st Century. Journal of Endangered Species Research. 11: 245-269.

Levenson DH, Eckert SA, Crognale MA, Deegan JF, Jacobs GH. 2004. Photopic Spectral Sensitivity of Green and Loggerhead Sea Turtles. Journal Copeia. 2004(4): 908-914.

Lewison RL, Crowder LB, Read AJ, Freeman SA. 2004. Understanding Impacts of Fisheries Bycatch on Marine Megafauna. TRENDS in Ecology and Evolution. 19: 598-604.

Liebman PA, Granda AM. 1975. Super Dense Carotenoid Spectra Resolved In Single Cone Oil Droplets. Journal Nature. 253: 370-372.

Lohmann KJ, Lohmann CMF, Endres CS. 2008. The Sensory Ecology of Ocean Navigation. The Journal of Experimental. 211: 1719-1728.

Mathger LM, Litherland L, Fritches KA. 2007. An Anatomical Study of the Visual Capabilities of the Green Turtle, Chelonia mydas. Journal Copeia. 2007(1): 169-179.

Nazir. 2009. Metode Penelitian. Bogor (ID): Ghalia Indonesia.

Ortiz N, Mangel JC, Wang JH, AlfaroShigueto J, Pingo S, Jimenez A, Suarez T, Swimmer Y, Carvalho F, Godley BJ. 2016. Reducing Green Turtle Bycatch in Small-Scale Fisheries Using Illuminated Gillnets: the Cost of Saving a Sea Turtle. Journal of Marine Ecology. 542: 251259.

Prasetyo GD, Wahju RI, Yusfiandayani R, Riyanto M. 2017. Light Emitting Diode (LED) Hijau dan Pengaruhnya terhadap Pengurangan Bycatch Penyu pada Perikanan Gillnet di Perairan Paloh. Marine Fisheries.
8(1): 87-99

Read AJ. 2007. Do Circle Hooks Reduce the Mortality of Sea Turtles in Pelagic Longlines? A Review of Recent Experiments. Biological Conservation I. 35: 155-169.

Schuyler QA, Wilcox C, Townsend K, Hardesty BD, Marshall NJ. 2014. Mistaken Identity? Visual Similarities of Marine Debrids to Natural Prey Items of Sea Turtles. Journal of Biomedcentral (BMC) Ecology. 14: 1-7.

Setyadji B, Nugraha B. 2012. Hasil Tangkap Sampingan (HTS) Kapal Tuna di Samudera Hindia yang Berbasis di Benoa. J. Lit. Perikan. Ind. 18(1): 4351.

Southwood AL, Fritsches KA, Brill R, Swimmer Y. 2008. Sound, Chemical, and Light Detection in Sea Turtle and Pelagic Fishes: Sensory Based Approaches to Bycatch Reduction in Longline Fisheries. Journal of Endangered Species Research. 5: 225-238.

Suprapti D. 2012. Status Populasi Penyu di Kecamatan Paloh, Kabupaten Sambas, Kalimantan Barat. Jakarta (ID): World Wild Fund-Indonesia Report.

Swimmer Y, Arauz R, Higgins B, McNaughton L, McCracken M, Ballestero J, Brill R. 2005. Food Color and Marine Turtle Feeding Behaviour: Can Blue Bait Reduce Turtle Bycatch in Commercial Fisheries. Journal of Marine Ecology Progress Series. 295: 273-278.

Ventura DF, Zana Y, De Souza JM, Devoe RD. 2001. Ultraviolet Colour Opponency in the Turtle Retina. The Journal of Experimental Biology. 204: 2527-2534.

Wahju RI, Ariyogautama D, Nugroho MPA, Armalinsyah F. 2014. Laporan Awal Analisa Ujicoba Lampu LED Hijau pada Alat Tangkap Jaring Insang di Perairan Paloh, Kabupaten Sambas. WWF Indonesia. 22 hal.

Wallace BP, Lewison RL, McDonald SL, Mc Donald RK, Kot CY, Kelez S, Bjorkland RK, Finkbeiner EM, Helmbrecht S, Crowder LB. 2010. Global Patterns of Marine Turtle Bycatch. Journal of Conservation Letters. 3: 131-142.

Wang $\mathrm{JH}$, Boles LC, Higgins B, Lohmann KJ. 2007. Behavioral Response of Sea Turtles to Lightsticks Used 
in Longline Fisheries. Animal

Conservation. 10(1): 176-182.

Wang JH, Fisler S, Swimmer Y. 2010.

Developing Visual Deterrents to

Reduce Sea Turtle Bycatch in Gillnet

Fisheries. Journal of Marine Ecology

Progress Series. 408: 241-250.

Wang JH, Swimmer Y. 2014. Developing a Turtle Safe Lightstick. Hawaii Fisheries Disaster Relief Program Final Report.

Witherington BE, Bjorndal KA. 1991. Influences of Wavelength and Intensity on Hatchling Sea Turtle Phototaxis: Implications for SeaFinding Behaviour. Journal Copeia. 1991: 1060-1069.

Wyneken J, Lohmann KJ, Musick JA. 2013. Biology of Sea Turtles Volume III. Amerika Serikat (ID): CRC Press. 446 hal.

Young M, Salmon M, Richard F. 2012. Visual Wavelength Discrimination by the Loggerhead Turtle, Caretta caretta. Journal of Marine Biological Laboratory. 222: 46-55. 